\title{
STUDY OF THE EFFECT OF RADIAL-SHEAR ROLLING ON THE MICROSTRUCTURE AND MECHANICAL PROPERTIES OF AUSTENITIC STAINLESS STEEL AISI-321
}

\author{
${ }^{1}$ Abdrakhman NAIZABEKOV, ${ }^{1}$ Sergey LEZHNEV, ${ }^{2}$ Alexandr ARBUZ, ${ }^{3}$ Yevgeniy PANIN \\ ${ }^{1}$ Rudny Industrial institute, Rudny, Kazakhstan, sergey legnev@mail.ru \\ ${ }^{2}$ Nazarbayev University, Astana, Kazakhstan, zubra kz@mail.ru \\ ${ }^{3}$ Karaganda state industrial university, Temirtau, Kazakhstan, cooper802@gmail.com \\ https://doi.org/10.37904/metal.2019.685
}

\begin{abstract}
The article presents the results of the study of the microstructure and mechanical properties of austenitic stainless steel AISI-321 after radial-shear rolling. The studies carried out in this work allowed to prove the possibility of obtaining the ultra-fine-grained structure in long-length blanks of austenitic stainless steel AISI-321 after radial-shear rolling, as well as to achieve a significant increase in the initial mechanical properties of this steel. Thus, in the course of experimental studies, bars from AISI-321 steel with a diameter of $13 \mathrm{~mm}$ with a grain size of 300-600 nm were obtained, while having an inhomogeneity in the cross section of the bar. The mechanical properties and microhardness of steel AISI-321 were increased more than 2 times compared to the original values.
\end{abstract}

Keywords: Radial-shear rolling, ultrafine-grained structure, stainless steel, mechanical properties, severe plastic deformation

\section{INTRODUCTION}

In the time of accelerated development of scientific and technological progress, the issue of obtaining new metal materials with improved complex mechanical and physical properties is very important task. One of the ways to improve both mechanical and operational properties is the use of metal materials with ultra-finegrained (UFG) structure. Such materials due to the small grain size contain a large number of grain boundaries in the structure, which affect their mechanical and physical properties. At the same time, grain boundaries should be predominantly small-angle, and the grains themselves should be equiaxed, with sizes less than 1 micron. Such structures provide a combination of a high level of strength characteristics with high plasticity, which fundamentally distinguishes such materials from conventional ones.

From all methods of obtaining sub-ultra-fine-grained materials the most promising is the severe plastic deformation, due to the possibility of obtaining isotropic products of a larger volume, without internal discontinuities. Thus, bringing the metal microstructure into an ultra-fine-grained state opens up great prospects in the field of material engineering [1-2].

Most of the methods of obtaining UFG materials by severe plastic deformation do not allow to provide a sufficient number of UFG materials with sufficient dimensions for commercial products. For example, the most frequently used and studied method as equal-channel angular pressing, has critical restrictions on the length of the resulting workpiece, which greatly complicates its industrial application [2].

To solve the problem of obtaining long-length blanks with UFG structure is possible by using radial-shear rolling (RSP) [3-4]. The difference between this method of rolling and conventional screw rolling is that a solid round bar is rolled according to a three-roll scheme with increased feed angles of the rolls, which contributes to the intensification of shear deformation and non-monotonicity of the metal flow under the predominance of the hydrostatic compression scheme [1]. Such conditions are favorable for the UFG structure formation, especially at low deformation temperatures. Therefore, this deformation method has a great potential for obtaining long metal products with UFG structure, because unlike other methods, it is as simple, effective and technological as possible. 
The aim of this work was to study the process of radial-shear rolling of austenitic stainless steel and identify its impact on the evolution of microstructure and mechanical properties.

\section{EXPERIMENTAL PROCEDURE}

Using the data of finite element simulation obtained earlier in works [5], it was decided to conduct a full-scale experiment for the conditions defined as optimal. Thus, the plan of the experiment included the rolling of rods with a $30 \mathrm{~mm}$ diameter on the radial-shear rolling mill SVP-08 to a $9 \mathrm{~mm}$ diameter in 7 passes with a compression $3 \mathrm{~mm}$ in each pass, at a temperature of $800{ }^{\circ} \mathrm{C}$ with a standard speed of rolls rotation $50 \mathrm{rpm}$. To eliminate the influence of reheating, it was decided to roll all bars with one heating the required number of passes, therefore, to study the evolution of the microstructure and mechanical properties, 7 samples were used, one sample for each final diameter. Two more samples were rolled to duplicate the results in each pass. The fourth and last passages were chosen as duplicates.

Each initial sample was a rod with a diameter of $30 \mathrm{~mm}$ and a length of $200 \mathrm{~mm}$. The sample material was austenitic stainless steel AISI-321 (0.08 \% C; 17-19 \% Cr; 9-11\% Ni; 2 \% Mn; $0.8 \%$ Si; 0.5-0.7 \% Ti). After achieving the desired diameter, the intense cooling of the rod with water was produced. A similar temperature regime for the production of stainless steel structure UFG was used in work [6].

After rolling from each bar on a high-precision cutting machine Struers AccuTom- 5 along the bar were cut samples in the form of strips $30 \times 3 \times 0.3 \mathrm{~mm}$ for mechanical testing, as well as prepared micro-plates for studying the microstructure evolution. Three strips from each point of the experiment (plus 3 strips from the duplicate samples for passes 4 and 7) were taken for the tensile test. Samples were also cut and prepared for mechanical testing and study of the microstructure of the starting material.

Mechanical properties were determined by tensile testing of flat specimens on the Instron-1195 test machine. For testing were taken from the strips, the central line of which is at a distance $1 / 2$ of the rod diameter that will allow to obtain the most objective results given the anticipated heterogeneity of the microstructure in the cross section of the rod. The test results for each point were averaged and presented as graphs in Figure 1.

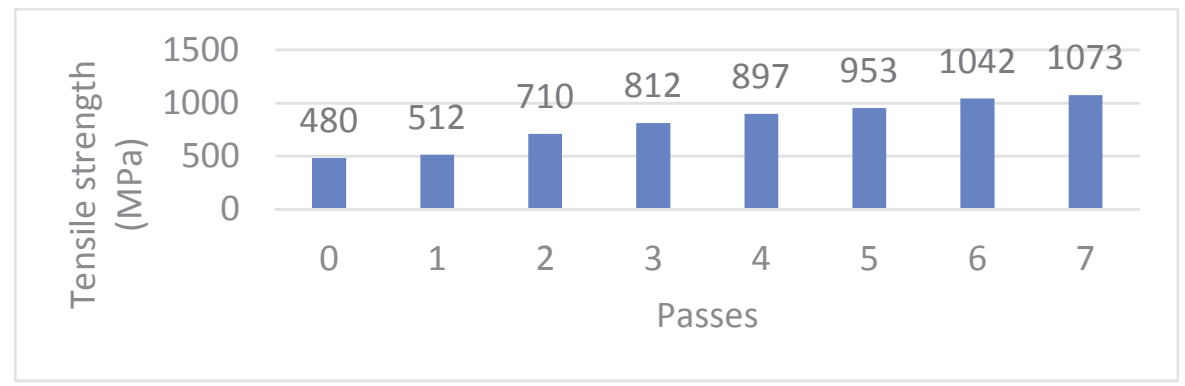

a) strength properties

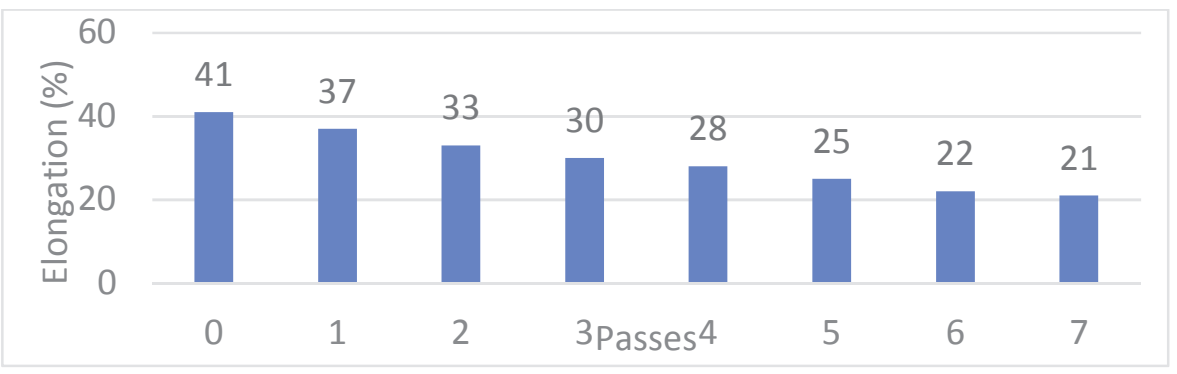

b) plastic properties

Figure 1 Mechanical properties of austenitic stainless steel AISI-321 after radial-shear rolling by passes 


\section{RESULTS AND DISCUSSION}

It can be concluded from the graphs that the mechanical properties change monotonically depending on the number of passes. At the same time, the tensile strength increased almost 2 times to a value of $1073 \mathrm{MPa}$, and the elongation, which is one of the indicators of material plasticity, is reduced by 2 times, reaching $21 \%$, against the initial $40 \%$. The decrease of elongation in this case is within the norm for materials that have undergone such processing and is comparable with the known data, for example, when this material is deformed by the ECAP method [7].

Further, using the remaining halves of the rod a study of the microhardness was performed. The measurements were carried out on hardness testing machine HVS-1000B with a force of $9.87 \mathrm{~N}$ at shutter speeds of 15 seconds. For each sample, 7 measurements were done at a distance of at least 2.5 imprint sizes from the point of the previous measurement. The initial micro-hardness was $160 \mathrm{HV}$. After radial-shear rolling, the microhardness level increased to $288-321 \mathrm{HV}$ and generally increased by 2 times compared to the original. The results were averaged over the passages and presented as a graph in Figure 2a.

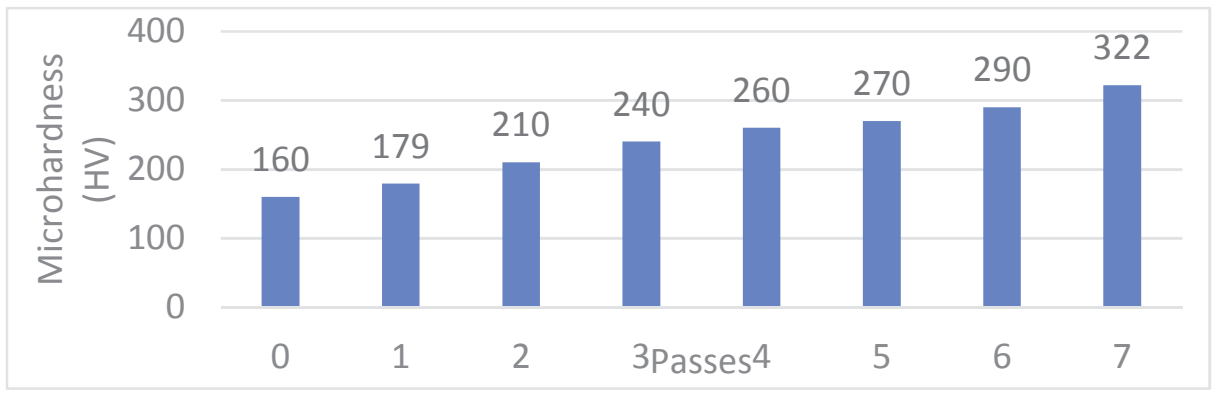

a) by passes

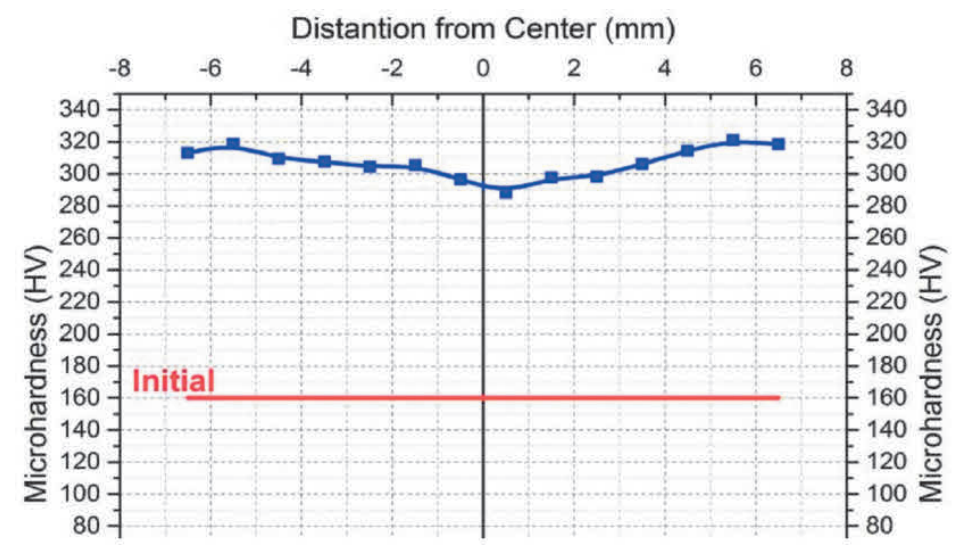

b) in the cross section of rod after the final pass

Figure 2 Microhardness HV of austenitic stainless steel AISI-321 after radial shear rolling

Taking into account the predicted heterogeneity of the microstructure at large deformations, it was decided to investigate the change in microhardness along the bar cross section for the last $7^{\text {th }}$ pass, since this sample will further serve for the preparation of samples for irradiation. In order to build the microhardness profile, measurements were carried out through each millimeter of the sample section 3 times at each point of the graph. The results for each point were averaged. The graph of change of microhardness on section is shown in Figure 2b.

As expected, due to the structural heterogeneity over the cross section of the rod is observed a gradual decline of the microhardness in the axial zone of the rod by $10.2 \%$ (33 HV). Otherwise, the level of microhardness is high enough throughout the cross section without sharp dips. 
Then the microstructure was studied using a transmission electron microscope (TEM). Samples were prepared by the electrolytic method in a solution (600 ml Methanol, $360 \mathrm{ml}$ Butylcellosolve, $60 \mathrm{ml}$ Perchloric Acid) and examined on transmission electron microscope JEM-2100 at an accelerating voltage of $200 \mathrm{kV}$. The microstructure was investigated in the center and the periphery of the cross section of the rod. The average grain size was calculated by secant method [8] by the most characteristic fields for each sample. The calculation was carried out on samples cut from the peripheral zone, since the largest grinding and formation of the required equiaxed UFG structure occurs exactly there (see Figure 3 ). This is also due to the fact that a fibrous texture with long elongated grains is formed in the axial zone on the last passes and therefore the determination of the average grain value is difficult and incorrect.

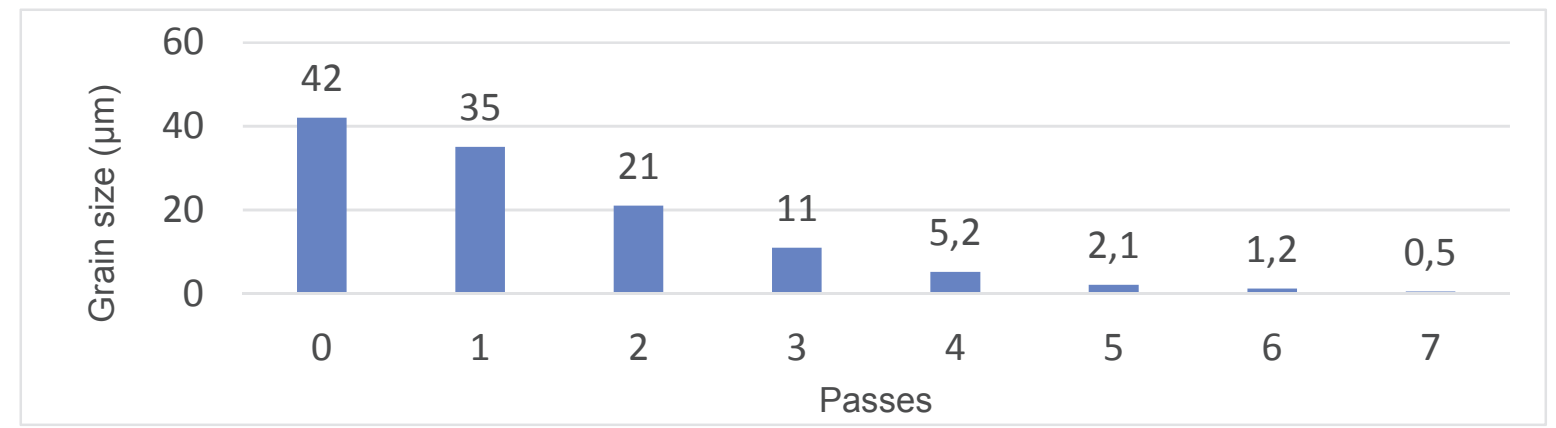

Figure 3 Changing the grain size of austenitic stainless steel AISI-321 after radial-shear rolling by passes

According to diagram displayed at Figure 3, it can be concluded that the most intensive grinding of the structure begins after the second pass, which can be explained by the saturation of the grains of the deformable layer with dislocations due to high degrees of deformation and low rolling temperature. The initial structure of steel AISI-321 in the state of delivery has a coarse-grained structure with a grain size of about 40 - 50 microns. After deformation with a total stretching equal 11, an ultra-fine-grained microstructure was obtained in the peripheral part of the rod with a grain size $(300-700 \mathrm{~nm})$ comparable to the results of known studies [9-10]. At the same time, it should be noted that the grains of the peripheral part have an equiaxed character. The structure of the axial zone of the bar consists of long and narrow grains elongated in the direction of rolling and resembling the texture of rolling. After the second pass, the grain size is monotonically halved for each pass and reaches an average size of $500 \mathrm{~nm}$ at the end of rolling, i.e. after the seventh pass. The microstructure of the peripheral and axial zones after seven passes is shown in Figure 4.

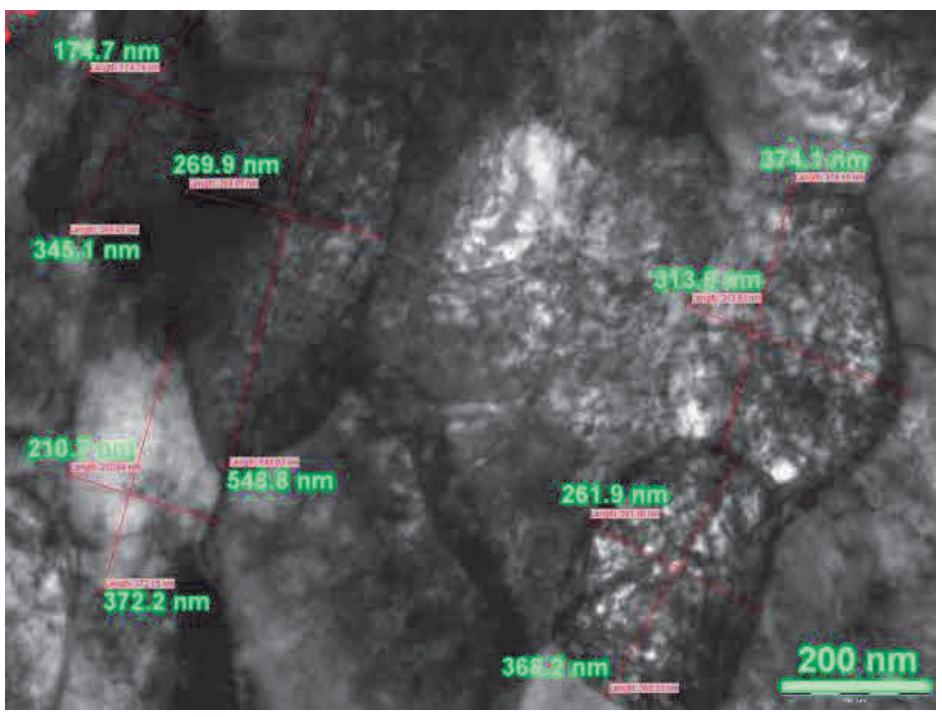

a) pheripheral zone 


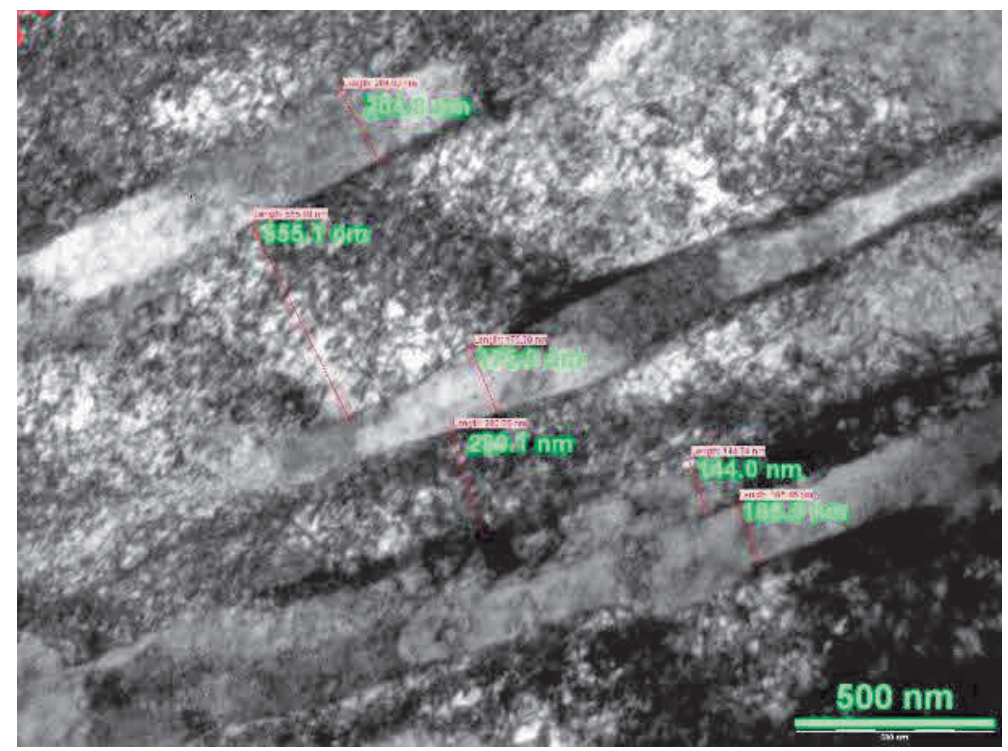

b) axial zone

Figure 4 Microstructure of peripheral and axial zones of austenitic stainless steel AISI-321 after radialshear rolling

\section{CONCLUSION}

Improvement the quality of ferrous metal products by grinding their structure to an ultra-fine-grained state is one of the main trends in modern materials science, however, the main problem of such materials is the small final size of blanks and low technological production. The performed studies allowed to prove the possibility of obtaining an ultra-fine-grained structure in long-length blanks of austenitic stainless steel AISI-321 by radial-shear rolling, as well as to achieve a significant increase in the initial mechanical properties of this steel. Thus, in the course of experimental studies, bars with a diameter of $9 \mathrm{~mm}$ were obtained from AISI-321 steel with a grain size of $300-600 \mathrm{~nm}$, while having an inhomogeneity in the cross section of the bar. The mechanical properties and microhardness of steel AISI-321 increased more than 2 times compared to the original values.

\section{ACKNOWLEDGEMENTS}

Work is performed under the state budget-funded theme № AP05131382 "Research and development of the technology for obtaining ultrafine-grained materials with improved mechanical properties and increased radiation resistance for their use as materials of the first wall of thermonuclear reactors and in nuclear power engineering" with the program "Grant financing of scientific researches on 2018-2020" (Customer - the Ministry of education and science of the Republic of Kazakhstan).

\section{REFERENCES}

[1] VALIEV, R. Z., ISLAMGALIEV, R. K. and ALEXANDROV, I. V. Bulk nanostructured materials from severe plastic deformation. Progress in Materials Science. 2000. vol. 45, no. 2, pp. 103-189.

[2] KOCH, C. C., OVID'KO, I. A., SEAL, S. and VEPREK, S. Structural nanocrystalline materials: Fundamentals and applications. Cambridge: Cambridge University Press, 2007. p. 128.

[3] ГАЛКИН, С. П. Способ винтовой прокатки. Патент Российской Федерации № 2293619. 2007, Бюллетень изобретений № 5. (GALKIN, S.P. Sposob vintovoj prokatki. Patent Rossijskoj Federacii № 2293619. 2007, Bjulleten' izobretenij № 5.) 
[4] GALKIN, S. P. Radial shear rolling as an optimal technology for lean production. Steel in Translation. 2014. vol. 44, no. 1, pp. 61-64.

[5] NAIZABEKOV, A., LEZHNEV, S., PANIN, E., ARBUZ, A. and KOINOV, T. Computer modelling of radial-shear rolling of austenitic stainless steel AISI-321. Machines, Technologies, Materials. 2018. vol. 12, pp. 497-500.

[6] АНДРИЕВСКИЙ, Р. А. Наноматериалы на металлической основе в экстремальных условиях. М.: Лаборатория знаний, 2016. 105 c. (ANDRIEVSKIJ, R. A. Nanomaterialy na metallicheskoj osnove $v$ jekstremal'nyh uslovijah. M.: Laboratorija znanij, 2016. 105 p.)

[7] РЫБАЛЬЧЕНКО, О. В., ТОКАРЬ, А. А., ТЕРЕНТЬЕВ, В. Ф., ПРОСВИРНИН, Д. В., РААБ, Г. И. and ДОБАТКИН, С. В. Влияние равноканального углового прессования в интервале температур 200-400 $\mathrm{C}$ на эксплуатационные свойства стали 08X18Н10T. VI Всероссийская конференция по наноматериалам с элементами научной школы для молодежи. 2016. С. 321-322 (RYBAL'CHENKO, O. V., TOKAR', A. A., TERENT'EV, V. F., PROSVIRNIN, D. V., RAAB, G. I. and DOBATKIN, S. V. Vlijanie ravnokanal'nogo uglovogo pressovanija $v$ intervale temperatur $200-400^{\circ} \mathrm{S}$ na jekspluatacionnye svojstva stali $08 \mathrm{H} 18 \mathrm{~N} 10 \mathrm{~T}$. VI Vserossijskaja konferencija po nanomaterialam s jelementami nauchnoj shkoly dlja molodezhi. 2016. pp. 321-322.).

[8] ГУляЕВ, А. П. Металловедение. М.: Металлургия, 1986. 544 с. (GULJAEV, А. P. Metallovedenie. M.: Metallurgija, 1986. 544 р.),

[9] ТОКАРЬ, А. А., РЫБАЛЬЧЕНКО, О. В., БЕЛЯКОВ, А. Н., ПРОСВИРНИН, Д. В., ТОРГАНЧУК, В. И., ТЕРЕНТЬЕВ, В. Ф., РААБ, Г. И. аnd ДОБАТКИН, С. В. Микроструктура и усталостные свойства аустенитной коррозионностойкой стали 08Х18Н10Т после равноканального углового прессования и последующего нагрева. Сборник трудов IX-ой Евразийской научно-практической конференции. 2018. C. 97 (TOKAR', A. A., RYBAL'CHENKO, O. V., BELJAKOV, A. N., PROSVIRNIN, D. V., TORGANCHUK, V. I., TERENT'EV, V. F., RAAB, G. I. and DOBATKIN, S. V. Mikrostruktura i ustalostnye svojstva austenitnoj korrozionnostojkoj stali 08H18N10T posle ravnokanal'nogo uglovogo pressovanija i posledujushhego nagreva. Sbornik trudov IX-oj Evrazijskoj nauchno-prakticheskoj konferencii. 2018. p. 97).

[10] NAIZABEKOV, A., LEZHNEV, S., ARBUZ, A. and PANIN, E. Combined process "helical rolling-pressing" and its effect on the microstructure of ferrous and non-ferrous materials. Metallurgical Research and Technology. 2018. vol. 115, article number 213, 11 p. 